\title{
Hubungan antara Faktor Reproduksi dengan Tumor Payudara Berdasarkan Pemeriksaan Sadanis, Riset Penyakit Tidak Menular 2016
}

\author{
THE RELATION BETWEEN REPRODUCTIVE FACTORS AND BREAST TUMOR BASED \\ ON CLINICAL BREAST EXAMINATION, NON COMMUNICABLE DISEASES RESEARCH 2016
}

\author{
Lusianawaty Tana*, Delima*, Hadjar Siswantoro, dan Armaji Kamaludi Syarif \\ Pusat Penelitian dan Pengembangan Sumber Daya dan Pelayanan Kesehatan \\ Badan Penelitian dan Pengembangan Kesehatan Kemenkes RI \\ Percetakan Negara No.29 Jakarta Pusat \\ *Email:puslitbangsdyankes@kemkes.go.id \\ *Email:Puslitbang.sd.yankes@gmail.com
}

Submitted:05-08-2019, Revised : 23-09-2019, Revised : 28-10-2019, Accepted : 11-11-2019

\begin{abstract}
Breast cancer is the most frequently diagnosed cancer in females worldwide. It was $18 \%$ of all cancer in 2012 and was in the fourth rank of mortality caused by cancer. Factors which is still speculated as risk factors of breast cancer are reproductive factors: never pregnant, only one pregnancy, and no breastfeeding. This secondary analysis of Non Communicable Diseases Research 2016 data aims to assess the relationship between reproductive factors with breast tumor among 43,948 Indonesian women of aged 25-64 years using logistic regression analysis with 5\% significance and 95\% confidence interval. The results showed breast tumor was higher in women aged 35 years and over compared with under 35 years, menarche at age 7-12 years compared with 13-25 years, first childbirth at 31-35 years and 36-47 years compared with under 30 years, having less than 3 children compared with $\geq 3$ children and no child or only 1 child breastfed compared with $\geq 2$ children breastfed. The analysis concluded that breast tumor was related to number of child breastfed, frequency of childbirth, and late first childbirth.
\end{abstract}

Keywords: breast tumor, reproductive, risk factor, clinical breast examination

\begin{abstract}
Abstrak
Kanker payudara merupakan kanker yang tersering pada perempuan di dunia yaitu $18 \%$ dari semua kasus kanker tahun 2012 dan sebagai penyebab kematian ke empat dari kematian karena kanker untuk semua jenis. Faktor risiko kanker payudara yang masih spekulasi antara lain faktor reproduksi, seperti tidak pernah hamil, hamil hanya sekali dan tidak menyusui. Analisis lanjut ini menganalisis faktor reproduksi terhadap tumor payudara pada perempuan di Indonesia dari Riset Penyakit Tidak Menular tahun 2016 dengan sampel 43.948 perempuan berusia 25-64 tahun. Data dianalisis dengan logistik regresi, tingkat kemaknaan 0,05 dan confidence interval $95 \%$. Hasil analisis menunjukkan tumor payudara meningkat 1,3 kali pada kelompok umur 35 tahun ke atas dibandingkan umur kurang dari 35 tahun, haid pertama pada umur 7-12 tahun dibandingkan dengan umur 13-25 tahun, umur melahirkan anak pertama 31-35 tahun dan 36-47 tahun dibandingkan umur kurang 30 tahun, jumlah anak kurang dari 3 orang dibandingkan 3 orang atau lebih dan tidak pernah menyusui anak/menyusui anak 1 orang dan menyusui 2 orang dibandingkan menyusui lebih dari 2 orang anak. Analisis menyimpulkan bahwa peningkatan tumor payudara berhubungan dengan banyaknya anak yang disusui, anak yang dilahirkan, dan peningkatan umur saat melahirkan anak pertama.
\end{abstract}

Kata kunci: Tumor payudara, reproduksi, faktor risiko, pemeriksaan payudara klinis 


\section{PENDAHULUAN}

Kanker payudara merupakan jenis kanker yang paling sering pada perempuan di dunia yaitu sebanyak $18 \%$ dari semua kasus kanker pada tahun 2012. Kanker payudara merupakan penyebab kematian peringkat keempat di antara semua kematian terkait kanker $(9 \%){ }^{1}$ Laporan penelitian lain tentang insiden kanker dan angka kematian kanker di seluruh dunia menunjukkan kanker payudara berada di urutan kedua setelah kanker paru. Persentase kanker payudara sebesar $11,9 \%$ dari semua kanker (tidak termasuk kanker kulit non melanoma). ${ }^{2}$

Insiden rate kanker payudara tinggi di Selandia Baru dan Australia, tetapi juga terjadi di beberapa negara Asia pada tahun terakhir. Peningkatan angka kematian akibat kanker payudara terjadi di banyak negara terutama Malaysia dan Thailand, sebaliknya cenderung stabil di Hongkong, Singapura, dan cenderung menurun di Australia dan Selandia baru. ${ }^{1}$

Faktor risiko yang mempengaruhi kanker payudara dilaporkan sebagai faktor yang dapat dirubah dan yang tidak dapat dirubah. Faktor kebiasaan merupakan faktor risiko kanker payudara yang dapat dirubah seperti obesitas postmenopause, kurangnya aktifitas fisik, terpajan radiasi dosis tinggi pada usia muda, kehamilan pertama usia tua ${ }^{3}$ sedangkan faktor risiko yang tidak dapat dirubah adalah umur, jenis kelamin, riwayat kanker payudara sebelumnya, penyakit tumor payudara jinak, faktor keturunan, menarche usia muda, dan menopause usia tua.

Faktor risiko digolongkan juga menjadi faktor risiko tetap, mungkin, dan masih dalam spekulasi. ${ }^{3}$ Faktor risiko yang sudah tetap untuk kanker payudara adalah jenis kelamin, umur, riwayat kanker payudara sebelumnya, tumor payudara jinak, faktor keturunan, menarche usia muda, menopause usia tua, usia tua pada kehamilan pertama, dan lain-lainnya. ${ }^{3}$

Beberapa faktor risiko yang tergolong sebagai mungkin pada kanker payudara telah dibuktikan oleh para ahli. ${ }^{3}$ Faktor risiko yang termasuk dalam spekulasi antara lain faktor reproduksi tidak pernah hamil, hanya satu kehamilan, tidak menyusui setelah melahirkan. Riwayat reproduksi dan menyusui, faktor risiko spesifik (riwayat kanker individu dan riwayat pemakaian terapi hormonal), dan faktor risiko bersama (indeks masa tubuh, perilaku, lingkungan). Perilaku konsumsi diet tinggi lemak, rendah serat, kurang makan buah-buahan dan sayuran dapat meningkatkan risiko kanker payudara sedangkan kebiasaan olahraga dapat menurunkan risiko kanker payudara. ${ }^{4,5}$

Terapi utama pada kanker payudara adalah pembedahan namun walaupun telah dilakukan pembedahan dan diterapi dan dinyatakan sembuh, kanker payudara dapat mengalami kekambuhan. ${ }^{6}$

Riset Penyakit Tidak Menular Tahun 2016 merupakan riset berbasis masyarakat yang informasinya mewakili perempuan di perkotaan tingkat nasional. Pada riset ini, data dikumpulkan melalui wawancara, pengukuran dan pemeriksaan. Pada wawancara dikumpulkan data karakteristik individu, tempat tinggal, dan riwayat reproduksi. Dari pemeriksaan payudara klinis (Sadanis) diperoleh data ada/tidak ada tumor payudara. ${ }^{7,8}$ Data tersebut digunakan untuk menganalisis hubungan antara faktor reproduksi terhadap tumor payudara pada perempuan di perkotaan di Indonesia.

Riset Penyakit Tidak Menular (PTM) 2016 adalah riset yang dilakukan di masyarakat yaitu perempuan umur 25-64 tahun di daerah perkotaan (urban) di Indonesia. Pada Riset PTM 2016 dikumpulkan antara lain data terkait faktor risiko, baik yang dapat dimodifikasi maupun tidak, faktor sosial ekonomi dan faktor riwayat reproduksi. Data diperoleh melalui wawancara terstruktur, pengukuran, dan pemeriksaan. Penentuan adanya tumor payudara diperoleh dari pemeriksaan payudara klinis (Sadanis) oleh bidan/dokter umum perempuan terlatih.

Analisis lanjut ini bertujuan menganalisis hubungan antara faktor reproduksi dengan tumor payudara berdasarkan pemeriksaan Sadanis. Hasil analisis diharapkan dapat memberi masukan mengenai peran faktor reproduksi terhadap tumor payudara dalam rangka melakukan upaya 
promotif dan preventif.

\section{BAHAN DAN METODE}

Penelitian ini merupakan analisis lanjut data Riset Penyakit Tidak Menular tahun 2016, dengan disain survei pada masyarakat secara potong lintang. Populasi adalah seluruh penduduk perempuan di Indonesia. Sesuai dengan sumber data, sampel adalah penduduk perempuan berusia 25-64 tahun di Indonesia. Kriteria sampel adalah tidak sedang hamil, dengan data lengkap dan tidak ekstrim (outlier). Jumlah sampel sesuai dengan kriteria sebesar 43.948 sampel. Data dikumpulkan berdasarkan wawancara dan pemeriksaan payudara klinis oleh bidan/dokter perempuan terlatih., ${ }^{7,8}$

Sebagai variabel terikat adalah tumor payudara dan variabel bebas adalah karakteristik individu (umur, pendidikan), riwayat reproduksi (menarche, umur melahirkan anak pertama, jumlah anak, jumlah anak yang disusui).

Umur dikelompokan menjadi 25-34 tahun, 35-44 tahun, 45-54 tahun, dan 55-64 tahun. Pendidikan dikategorikan menjadi rendah (tidak sekolah, tidak tamat SD, tamat SD, dan SLTP), menengah (SLTA dan sederajat), dan tinggi (perguruan tinggi/akademi). Umur saat mendapat menarche dikategorikan menjadi 7-12 tahun dan 13-25 tahun. Umur melahirkan anak pertama dikategorikan dalam 10-30 tahun, 3135 tahun, dan 36-47 tahun. Jumlah anak yang dilahirkan dikategorikan tidak ada, 1-2 anak, 3-4 anak, 5-6 anak, dan lebih 6 tahun. Jumlah anak yang disusui dikategorikan menjadi tidak ada, 1 orang, 2 orang, 3-5 orang, dan 6-10 orang.

Sebagian besar pengkategorian variabel penelitian ini sesuai dengan sumber data. ${ }^{7}$ Oleh karena data Riset PTM 2016 telah dianalisis dari aspek lain, maka tidak dapat dihindarkan kemungkinan adanya penggunaan dan pengkategorian variabel yang sama.

Data dianalisis secara univariat, bivariat dan multivariat, menggunakan komplex sampel program SPSS 16,0 Family, serial 5055095.
Tingkat kemaknaan ditentukan sebesar $\leq 0,05$ dan confidence interval sebesar 95\%.

\section{HASIL}

Jumlah sampel yang memenuhi kriteria untuk dianalisis sebanyak 43.948 sampel. Proporsi sampel berdasarkan karakteristik individu disajikan dalam tabel di bawah ini.

Sebagian besar sampel beusia antara 35-44 tahun (33,2\%), disusul usia 25-34 tahun $(30,7 \%)$, dengan tingkat pendidikan menengah $(56,0 \%)$. Hampir tiga dari empat responden mengalami menarche pada umur 7-12 tahun. Sebagian besar melahirkan anak pada umur antara 10-30 tahun (87,4\%), terbanyak memiliki anak 1-2 orang (49,9\%), sedangkan yang memiliki anak 3-4 orang sebanyak 32\%, namun sekitar 18\% memiliki anak lebih 4 orang. Sampel yang tidak pernah menyusui anak 16,6\%, terbanyak menyusui anak 3-5 anak $(32,1 \%)$ dan menyusui 2 anak sebesar 31,1\%. Sebanyak 8,1\% sampel didiagnosis dengan tumor berdasarkan pemeriksaan payudara klinis.

Hubungan bivariat antara karakteristik dan riwayat reproduksi dengan tumor payudara disajikan pada tabel di bawah ini.

Sebagian besar sampel beusia antara 35-44 tahun (33,2\%), disusul usia 25-34 tahun $(30,7 \%)$, dengan tingkat pendidikan menengah (56,0\%). Hampir tiga dari empat responden mengalami menarche pada umur 7-12 tahun. Sebagian besar melahirkan anak pada umur antara 10-30 tahun (87,4\%), terbanyak memiliki anak 1-2 orang (49,9\%), sedangkan yang memiliki anak 3-4 orang sebanyak 32\%, namun sekitar 18\% memiliki anak lebih 4 orang. Sampel yang tidak pernah menyusui anak 16,6\%, terbanyak menyusui anak 3-5 anak $(32,1 \%)$ dan menyusui 2 anak sebesar 31,1\%. Sebanyak 8,1\% sampel didiagnosis dengan tumor berdasarkan pemeriksaan payudara klinis.

Hubungan bivariat antara karakteristik dan riwayat reproduksi dengan tumor payudara disajikan pada tabel di bawah ini. 
Tabel 1. Proporsi Sampel Berdasarkan Karakteristik Individu dan Riwayat Reproduksi, Riset PTM 2016

\begin{tabular}{|c|c|c|}
\hline Karakteristik/riwayat reproduksi & $\mathbf{N}$ tertimbang & Persen (\%) \\
\hline \multicolumn{3}{|l|}{ Kelompok umur (tahun) } \\
\hline$\cdot 55-64$ & 3.279 .707 & 12,8 \\
\hline$\bullet 45-54$ & 5.999 .537 & 23,3 \\
\hline - 35-44 & 8.530 .809 & 33,2 \\
\hline -25-34 & 7.894 .666 & 30,7 \\
\hline \multicolumn{3}{|l|}{ Pendidikan } \\
\hline • Rendah & 8.590 .767 & 33,4 \\
\hline - Menengah & 14.396 .851 & 56,0 \\
\hline - Tinggi & 2.717 .101 & 10,6 \\
\hline \multicolumn{3}{|l|}{ Umur menarche (tahun) } \\
\hline$\cdot 7-12$ & 18.238 .062 & 71,0 \\
\hline$\cdot 13-25$ & 7.456 .101 & 29,0 \\
\hline - Tidak menjawab & 10.556 & 0,0 \\
\hline \multicolumn{3}{|l|}{ Umur melahirkan anak pertama (tahun) } \\
\hline$\cdot 36-47$ & 232.545 & 0,9 \\
\hline$\cdot 31-35$ & 832.295 & 3,2 \\
\hline$\cdot 10-30$ & 22.458 .668 & 87,4 \\
\hline - Tidak melahirkan & 2.181 .211 & 8,5 \\
\hline \multicolumn{3}{|l|}{ Jumlah anak (orang) } \\
\hline - Tidak ada & 2179768 & 8,5 \\
\hline$\cdot 1-2$ & 12831420 & 49,9 \\
\hline$\cdot 3-4$ & 8219463 & 32,0 \\
\hline$\cdot \geq 5$ & 2474068 & 9,6 \\
\hline \multicolumn{3}{|l|}{ Jumlah anak yang disusui (orang) } \\
\hline • Tidak ada & 4.259 .587 & 16,6 \\
\hline$\cdot 1$ & 4.220 .458 & 16,4 \\
\hline$\cdot 2$ & 8.004 .370 & 31,1 \\
\hline$\cdot 3-5$ & 8.247 .962 & 32,1 \\
\hline$\cdot 6-10$ & 972.343 & 3,8 \\
\hline \multicolumn{3}{|l|}{ Tumor payudara } \\
\hline • Ada tumor & 2.070 .524 & 8,1 \\
\hline - Bukan tumor & 23.634 .195 & 91,9 \\
\hline Total & 25.704 .719 & 100,0 \\
\hline
\end{tabular}

Tabel 2. Hubungan Karakteristik Individu dan Riwayat Reproduksi dengan Tumor Payudara

\begin{tabular}{|c|c|c|c|c|c|c|}
\hline \multirow{2}{*}{ Karakteristik/Riwayat Reproduksi } & \multicolumn{2}{|c|}{ Tumor payudara (\%) } & \multirow[t]{2}{*}{ OR } & \multicolumn{2}{|c|}{$95 \% \mathrm{CI}$} & \multirow{2}{*}{$\mathbf{p}$} \\
\hline & Ya & Tidak & & lower & upper & \\
\hline \multicolumn{7}{|l|}{ Kelompok umur (tahun) } \\
\hline$\cdot 35-64$ & 8,2 & 91,8 & 1,06 & 1,05 & 1,06 & 0,0001 \\
\hline • 25-34 & 7,8 & 92,2 & 1 & & & \\
\hline \multicolumn{7}{|l|}{ Pendidikan } \\
\hline - Rendah & 7,6 & 92,4 & 1 & & & \\
\hline - Menengah & 7,9 & 92,1 & 1,37 & 1,36 & 1,37 & \\
\hline • Tinggi & 10,2 & 89,8 & 1,32 & 1,31 & 1,32 & 0,0001 \\
\hline \multicolumn{7}{|l|}{ Umur menarche (tahun) } \\
\hline$\cdot 7-12$ & 8,1 & 91,9 & 1,01 & 1,01 & 1,02 & 0,0001 \\
\hline$\cdot 13-25$ & 8,0 & 92,0 & 1 & & & \\
\hline
\end{tabular}




\begin{tabular}{|c|c|c|c|c|c|c|}
\hline \multicolumn{7}{|c|}{ Umur melahirkan anak pertama (tahun) } \\
\hline$\cdot 36-47$ & 12,0 & 88,0 & 1,33 & 1,31 & 1,35 & \\
\hline$\cdot 31-35$ & 9,3 & 90,7 & 1,67 & 1,65 & 1,69 & 0,0001 \\
\hline • $10-30$ & 7,6 & 92,4 & 1 & & & \\
\hline \multicolumn{7}{|c|}{ Jumlah anak (orang) } \\
\hline - Tidak ada & 12,1 & 87,9 & 2,24 & 2,23 & 2,26 & 0,0001 \\
\hline$\cdot 1-2$ & 8,2 & 91,8 & 1,73 & 1,72 & 1,74 & \\
\hline$\cdot 3-4$ & 7,4 & 92,6 & 1,54 & 1,54 & 1,55 & \\
\hline$\bullet \geq 5$ & 5,9 & 94,1 & 1 & & & \\
\hline \multicolumn{7}{|c|}{ Jumlah anak yang disusui (orang) } \\
\hline Tidak ada & 11,0 & 89,0 & 2,04 & 2,03 & 2,06 & 0,0001 \\
\hline$\bullet 1$ & 8,5 & 91,5 & 1,65 & 1,64 & 1,66 & \\
\hline$\cdot 2$ & 7,7 & 92,3 & 1,47 & 1,47 & 1,48 & \\
\hline • $3-5$ & 6,9 & 93,1 & 1,33 & 1,33 & 1,34 & \\
\hline$\cdot>5$ & 5,7 & 94,3 & 1 & & & \\
\hline
\end{tabular}

Tabel 3. Hubungan Multivariat antara Karakteristik Individu dan Riwayat Reproduksi dengan Tumor Payudara

\begin{tabular}{|c|c|c|c|c|}
\hline \multirow{2}{*}{ Karakteristik/Riwayat Reproduksi } & \multirow[t]{2}{*}{ OR } & \multicolumn{2}{|c|}{$95 \% \mathrm{CI}$} & \multirow{2}{*}{$\mathbf{p}$} \\
\hline & & bawah & atas & \\
\hline \multicolumn{5}{|l|}{ Kelompok umur (tahun) } \\
\hline • 35-64 & 1,28 & 1,28 & 1,29 & 0,0001 \\
\hline$\cdot 25-34$ & 1 & & & \\
\hline \multicolumn{5}{|l|}{ Pendidikan } \\
\hline - Rendah & 1,16 & 1,15 & 1,17 & 0,0001 \\
\hline - Menengah & 1,16 & 1,15 & 1,16 & 0,0001 \\
\hline - Tinggi & 1 & & & \\
\hline \multicolumn{5}{|l|}{ Umur menarche (tahun) } \\
\hline$\cdot 7-12$ & 1,04 & 1,04 & 1,04 & 0,0001 \\
\hline$\cdot 13-25$ & 1 & & & \\
\hline \multicolumn{5}{|l|}{ Umur melahirkan anak pertama (tahun) } \\
\hline$\cdot 36-47$ & 1,27 & 1,25 & 1,29 & 0,0001 \\
\hline$\cdot 31-35$ & 1,32 & 1,31 & 1,34 & 0,0001 \\
\hline$\cdot 10-30$ & 1 & & & \\
\hline \multicolumn{5}{|l|}{ Jumlah anak (orang) } \\
\hline$\cdot 1-2$ & 1,39 & 1,37 & 1,40 & 0,0001 \\
\hline$\cdot 3-4$ & 1,07 & 1,07 & 1,08 & 0,0001 \\
\hline$\cdot \geq 5$ & 1 & & & \\
\hline \multicolumn{5}{|l|}{ Jumlah anak yang disusui (orang) } \\
\hline - Tidak pernah & 1,39 & 1,37 & 1,41 & 0,0001 \\
\hline$\bullet 1$ & 1,38 & 1,37 & 1,39 & 0,0001 \\
\hline$\cdot 2$ & 1,29 & 1,29 & 1,30 & 0,0001 \\
\hline$\cdot 3-5$ & 1,13 & 1,12 & 1,13 & 0,0001 \\
\hline$\cdot>5$ & 1 & & & \\
\hline
\end{tabular}

Hasil analisis multivariat awal dari enam variabel yang dianalisis secara multivariat, didapatkan semuanya berhubungan bermakna dengan tumor payudara. Enam variabel yang berhubungan bermakna terhadap tumor payudara tersebut adalah berturut-turut jumlah anak yang disusui, jumlah anak, umur saat melahirkan anak pertama, kelompok umur, pendidikan, dan umur menarche. 


\section{PEMBAHASAN}

Ditinjau dari hubungan kelompok umur terhadap tumor payudara, hasil penelitian ini menunjukkan tumor payudara berdasarkan pemeriksaan Sadanis pada kelompok umur 35-64 tahun lebih tinggi secara bermakna dibandingkan kelompok umur 25-34 tahun.

Hasil penelitian ini sesuai dengan penelitian tentang faktor risiko kanker payudara, yang melaporkan bahwa umur merupakan salah satu faktor risiko disamping jenis kelamin dan riwayat keluarga, yang merupakan faktor risiko kanker payudara yang tidak dapat dirubah. ${ }^{3}$

Menurut Statistik Kanker (Surveillance, Epidemiology, and End Results Data Base), risiko kanker payudara meningkat dengan bertambahnya umur. Kemungkinan seorang perempuan di Amerika Serikat mengalami kanker payudara pada umur $\leq 39$ tahun adalah 1 di antara 202 orang, pada umur 40-59 tahun meningkat menjadi 1 di antara 26 orang, dan sedikit menurun pada umur pada umur 60-69 tahun menjadi 1 di antara 28 orang. ${ }^{9}$

Meningkatnya kanker payudara sesuai dengan peningkatan umur menunjukkan keterlibatan hormon reproduksi yang dihasilkan oleh ovarium dan kelenjar adrenalin terhadap patogenesis kanker payudara. Hal ini berbeda dibandingkan kanker lain yang tidak responsif terhadap hormon reproduksi, yang menunjukkan tidak ada perubahan insiden selama masa reproduksi perempuan. ${ }^{10}$

Penelitian lain telah dilakukan dengan mengobservasi sel stroma payudara yang dapat mempengaruhi pertumbuhan sel epitel normal atau tidak normal payudara dan yang dapat mensekresi faktor pertumbuhan mengikuti stimulasi hormon yang dihasilkan dalam tubuh. Jaringan penunjang mengandung enzym aromatase dan menghasilkan hormon estradiol dari cholesterol darah. Oleh karena proporsi sel lemak lebih tinggi pada payudara perempuan dengan usia yang lebih tua, maka tingkat hormon estradiol dalam jaringan payudara pada perempuan menopause lebih banyak dibandingkan dalam plasma. Hal ini dikaitkan dengan peningkatan insiden kanker payudara berdasarkan usia tua dan mendukung peranan hormon steroid dalam patogenesis kanker payudara. ${ }^{11}$

Peranan hormon steroid terhadap proses karsionegenesis telah dibuktikan setelah tindakan bedah mengangkat ovarium, akan diikuti dengan penurunan tingkat hormon dalam darah dan terbukti perbaikan pada wanita dengan kanker payudara. ${ }^{10}$

Eremanetal. melaporkan penghentian dan penurunan penggunaan terapi hormon estrogen progesteron konsisten dengan penurunan insiden kanker payudara khususnya kanker payudara jenis estrogen reseptor positif. ${ }^{12}$

Dalam diagram piramid faktor risiko dan pencegahan kanker payudara, maka 5 faktor penting terhadap kejadian kanker payudara adalah umur, riwayat keluarga, reproduksi, estrogen dan gaya hidup. ${ }^{13}$

Dari hasil multivariat didapatkan pendidikan merupakan salah satu faktor yang berhubungan bermakna terhadap tumor payudara. Semakin tinggi pendidikan berhubungan dengan semakin tinginya kejadian tumor payudara. Penjelasan terkait hal ini adalah pada responden dengan pendidikan yang lebih tinggi maka pengetahuan tentang kesehatan lebih baik dibandingkan dengan pendidikan yang lebih rendah, termasuk keinginan untuk memeriksakan diri. Hal ini didukung dari hasil penelitian yang melaporkan kelompok dengan pendidikan tamat perguruan tinggi lebih banyak yang melakukan pemeriksaan payudara sendiri. Analisis logistik regresi mengidentifikasi kelompok lulusan perguruan tinggi melakukan Sadanis 1,8 kali lebih tinggi. ${ }^{14}$

Faktor risiko kanker payudara adalah jenis kelamin, umur, riwayat kanker payudara sebelumnya, penyakit tumor payudara jinak, faktor keturunan, menarche usia muda, menopause umur tua, kehamilan pertama pada umur tua, obesitas postmenopause, kurangnya aktivitas fisik, terpajan radiasi dosis tinggi pada usia muda. ${ }^{3}$

Pada penelitian ini didapatkan hasil bahwa tumor payudara meningkat pada perempuan dengan menarche pada umur muda 7- 12 tahun dibandingkan pada umur 13-25 tahun. Hasil 
penelitian ini sesuai dengan kepustakaan yang melaporkan bahwa menarche pada usia muda merupakan faktor risiko kanker payudara. ${ }^{3}$

Dilaporkan bahwa umur menarche dan menopause berkontribusi terhadap lamanya pajanan terhadap efek karsinogenik hormon sexual. Penelitian Aguas et al. melaporkan risiko kanker payudara berkurang sampai $15 \%-20 \%$ dari terlambatnya menarche setiap tahun. ${ }^{15}$ Demikian juga menopause yang terlambat dari 55 tahun ke atas merupakan faktor risiko. Hal ini karena pada menarche lebih awal dan menopause yang lebih lama akan meningkatkan durasi pajanan terhadap estrogen pada tahun reproduksi seorang perempuan. Namun pada perkembangan kanker payudara terdapat kolaborasi antara faktor genetik dan lingkungan. ${ }^{15}$

Umur menarche dini merupakan faktor risiko di antara perempuan pre dan postmenopausal dalam berkembangnya kanker payudara. Menache yang 2 tahun lebih lambat datangnya berhubungan denga penurunan risiko sampai $10 \% .^{16}$

Penelitian lain melaporkan, perempuan yang mendapatkan menarche kurang dari umur 14 tahun berhubungan dengan peningkatan hampir 2 kali lipat risiko tumor yang termasuk dalam tumor hormon reseptor positif. ${ }^{17}$

Giles et al. melaporkan perempuan yang menarche pada umur lebih muda akan menurunkan kemampuan hidup untuk sampai pada umur tua. Hasil ini mendukung penjelasan tentang adanya hubungan antara menarche dini dengan risiko penyakit metabolik di masa dewasa muda. ${ }^{18}$ Zhang et al. membuktikan adanya perubahan faktor risiko yang berperan terhadap kanker payudara, yaitu pergeseran ke arah lebih muda umur menarche, menurunnya lama kehamilan, lebih singkatnya masa menyusui. Perubahan ini dihubungkan dengan meningkatnya insiden kanker payudara di Tiongkok. ${ }^{19}$

Faktor reproduksi seperti menarche dini, menopause terlambat, umur tua pada kehamilan pertama dan melahirkan anak sedikit dapat meningkatkan risiko kanker payudara. Disebutkan keterlambatan 1 tahun menopause akan meningkatkan risiko kanker payudara 3\%.
Setiap keterlambatan menarche 1 tahun atau tambahan kelahiran anak akan mengurangi risiko kanker payudara $5 \%$ atau $10 \%{ }^{20,21}$

Pada penelitian ini didapatkan umur saat melahirkan anak pertama merupakan faktor penting yang berperan terhadap tumor payudara. Penelitian lain melaporkan kanker payudara biasa dijumpai pada perempuan yang tidak subur dan yang tidak menyusui bayinya. Kehamilan pertama pada umur muda, khususnya apabila dihubungkan dengan menarche yang lebih lambat dan menopause yang lebih dini. Untuk melindungi terhadap kanker payudara adalah menurunkan durasi pajanan terhadap hormon estrogen. ${ }^{10}$

Risiko payudara menurun pada perempuan yang melahirkan umur kurang dari 20 tahun dibandingkan umur lebih dari 30 tahun. Pada perempuan umur kurang dari 20 tahun yang hamil cukup bulan dan jumlah kehamilan lebih dari satu kali akan mengurangi risiko kanker payudara separuhnya dibandingkan yang tidak pernah melahirkan anak. Hal ini dikarenakan tingkatestrogenyang lebihrendahpadakehamilan dan pada perempuan yang memiliki anak banyak. ${ }^{10}$ Namun sebaliknya, ada pula peneliti yang melaporkan tidak ada hubungan antara jumlah kehamilan dengan kanker payudara. ${ }^{22}$ Selain kehamilan yang perlu diperhatikan adalah faktor menyusui sebagai faktor yang melindungi terhadap kanker payudara. ${ }^{23}$

Umur muda pada saat melahirkan pertama kali memiliki efek pelindung secara keseluruhan, sebaliknya umur tua pada kehamilan pertama akan berisiko relatif lebih tinggi terhadap terjadinya kanker payudara dibandingkan dengan perempuan yang tidak pernah melahirkan anak. ${ }^{23}$ Dibandingkan dengan perempuan yang tidak pernah melahirkan anak maka insiden kumulatif kanker payudara pada saat melahirkan umur 20 tahun, 25 tahun, dan 35 tahun adalah lebih rendah $20 \%, 10 \%$, dan $5 \% .^{23}$

Penelitian studi kohort Norwegia menunjukkan rasio berbahaya hormon reproduksi adalah umur terlambat saat melahirkan anak pertama atau umur $\geq 35$ tahun pada saat melahirkan anak pertama berisiko 1,5 kali dibandingkan dengan umur $<20$ tahun saat 
melahirkan anak pertama. ${ }^{21}$

Ditinjau dari jumlah anak yang dilahirkan didapatkan makin sedikit anak yang dilahirkan maka tumor payudara semakin meningkat. Hal ini ditunjang oleh kepustakaan yang menyebutkan perempuan yang tidak pernah melahirkan anak akan meningkat risiko berkembangnya kanker payudara dibandingkan perempuan yang pernah melahirkan anak..$^{23}$

Pada penelitian ini didapatkan perempuan yang menyusui anak lebih banyak lebih dari 3 orang berisiko lebih rendah dibandingkan perempuan yang menyusui anak kurang dari 3 orang atau tidak pernah menyusui. Penelitian Collaborative Group on Hormonal Factors in Breast Cancer membuktikan bahwa menyusui anak memiliki efek pelindung terhadap berkembangnya kanker payudara. Menyusui anak akan menunda kembalinya siklus ovarium dan menurunkan tingkat hormon sexual yang dihasilkan dari dalam tubuh. Diperkirakan terdapat $4,3 \%$ pengurangan kanker payudara dari setiap 1 tahun menyusui. ${ }^{24}$

Dalam rangka pencegahan kanker payudara, Ranasinghe et al. melaporkan pengetahuan, sikap dan praktek tentang kanker payudara di masyarakat kurang, khususnya pemeriksaan payudara sendiri. ${ }^{25}$ Demikian juga penelitian Liu et al. menunjukkan kewaspadaan terhadap kanker payudara di antara perempuan umur 25-70 tahun di Bagian Timur Tiongkok hanya $18,6 \%$ yang waspada sedangkan $81,4 \%$ tidak waspada. ${ }^{26}$

Program intervensi diperlukan untuk mempromosikan pentingnya mulai menyusui dini dan memperpanjang masa menyusui eksklusif. ${ }^{27}$ Selain itu, promosi kesehatan terkait diet rendah lemak, tinggi serat, banyak buah dan sayuran, kebiasaan berolahraga dapat menurunkan risiko kanker payudara. ${ }^{4,5}$

\section{KESIMPULAN}

Faktor reproduksi yang berhubungan terhadap tumor payudara pada perempuan umur 25-64 tahun di Indonesia adalah jumlah anak yang disusui, jumlah anak yang dilahirkan, umur saat melahirkan anak pertama, kelompok umur, pendidikan dan umur saat menarche.

Tumor payudara meningkat berhubungkan dengan semakin sedikit anak yang disusui, semakin sedikit jumlah anak yang dilahirkan, semakin tua umur saat melahirkan anak pertama, dan semakin tua umur seorang perempuan.

Penyuluhan perlu ditingkatkan terkait pentingnya menyusui anak pada perempuan yang melahirkan dalam rangka pencegahan tumor payudara.

\section{UCAPAN TERIMA KASIH}

Terima kasih disampaikan kepada Dr. dr. Irmansyah, Sp.KJ(K) selaku Kepala Pusat Penelitian dan Pengembangan Sumber Daya dan Pelayanan Kesehatan Badan Litbangkes Kemenkes RI. Ucapan terima kasih kami sampaikan pula kepada Sekretariat Badan Litbangkes Kemenkes RI yang telah memberi kesempatan melakukan analisis data Riset Penyakit Tidak Menular 2016.

\section{DAFTAR RUJUKAN}

1. Youlden DR, Cramb SM, Cheng HY, Baade PD. Incidence and mortality of female breast cancer in the Asia-Pacific region. Cancer Biol Med 2014. 11 (2) 101-115. Doi: 107497/ J.issn. 2095-3941. 2014. 02.005. [Cited at 7 March 2016]. Available from: https://www. ncbi.nlm.nih.gov/pmc/articles/PMC4069805/.

2. Ferlay J, Soerjomataram I, Ervik M, Dikshit R, Eser S, Mathers C, Rebelo M, Parkin DM, Forman D, Bray, F., Cancer Incidence and Mortality Worldwide: IARC CancerBase No. 11. GLOBOCAN 2012 v1.1. Lyon, France: International Agency for Research on Cancer; 2014. [Cited at 16 January 2015]. Available from: http://globocan.iarc.fr.

3. Meister K, Morgan J. Risk factors for breast cancer. A Report by the American Council on Science and Health (ACSH).2000. [Cited at March 2016]. Available from: https://www.acsh.org/wp-content/ uploads/2012/04/20070814_risk_Breast.pdf .

4. National Cancer Institute. Breast Cancer Risk in American Women - National Cancer 
Institute. (2012). [Cited at 24th October 2016]. Available from: http://www.cancer.gov/types/ breast/risk-fact-sheet.

5. National Cancer Institute. Cancer-Causing Substances in the Environment - National Cancer Institute. (2015). [Cited at 24th October 2016]. Available at: http://www. cancer.gov/about-cancer/causes-prevention/ risk/substances.

6. Purwanto, H., Handoyo, D., Haryono,S. and Harahap, W. Panduan Penatalaksanaan Kanker Payudara. Jakarta. PERABOI. 2015;15-21:4045.

7. Badan Penelitian dan Pengembangan Kesehatan. Laporan Riset Penyakit Tidak Menular Tahun 2016. Jakarta: Badan Penelitian dan Pengembangan Kesehatan; 2017.

8. Badan Penelitian dan Pengembangan Kesehatan. Pedoman pengisian kuesioner Riset Penyakit Tidak Menular 2016. Jakarta: Badan Penelitian dan Pengembangan Kesehatan; 2016.

9. Siegel R, Naishadham D, Jemal A. Cancer statistics, 2013. CA Cancer J Clin. 2013;63:1130. [PubMed] [GoogleScholar] [Cited at 7 March 2016]. Available from: https:// onlinelibrary.wiley.com/doi/full/10.3322/ caac. 21166.

10. Abdulkareem IH. Sabiston DC, Lyerly HK. 15th ed. Philadelphia: WB Saunders Company; 1997. Sabiston textbook of surgery: The biological basis of modern surgical practice. In Abdulkareem IH. Aetio-pathogenesis of breast cancer. Niger Med J. 2013 NovDes;54(6):371-375. [Cited at March 2019]. Available from: https://www.ncbi.nlm.nih. gov/pmc/articles/PMC3948957/.

11. Malara NM, Leotta A, Sidoti A, Lio S, D’Angelo R, Caparello B, et al. Ageing, Hormonal behaviour and cyclin D1 in ductal breast carcinomas.Breast.2006;15:81-9.

12. Ereman RR, Prebil LA, Mockus M, Koblick K, Orenstein F, Benz C, Clarke CA. Recentiltrends in hormone therapy utilization and breast cancer incidence rates in the high incidence population of Marin County, California. BMC Public Health 2010,
10:228. [Cited 6 November 2019]. Available from:http:/www.biomedcentral.com/14712458/10/228.

13. Sun YS, Zhao Z, Yang ZNv, Xu F, Lu HJ, Zhu ZY, et al. Risk Factors and Preventions of Breast Cancer. Int J Biol Sci. 2017;13 (11): 1387-1397. Published online 2017 Nov 1. doi: 10.7150/ijbs.21635 [Cited at March 2019]. Available form: https://www.ncbi.nlm.nih. gov/pmc/articles/PMC5715522/.

14. Gurdal SO, Saracoglu GV, Oran ES, Yankol Y, Soybir GR. The effects of educational level on breast cancer awareness: a cross-sectional study in Turkey. Asian Pac J Cancer Prev, 2012;13(1): 295-300. [Cited at March 2019]. Available from: https://www.ncbi.nlm.nih. gov/pubmed/22502688.

15. Aguas F, Martins A, Gomes TP, de Sousa M, Silva DP. Portuguese Menopause Society and Portuguese Gynaecology Society. Prophylaxis approach to a-symptomatic postmenopausal women: Breast cancer. Maturitas. 2005;52(Suppl 1):S23-31.

16. Hsieh CC, Trichopoulos D, Katsouyanni K, Yuasa S. Age at menarche, age at menopause, height and obesity as risk factors for breast cancer: associations and interactions in an international case-control study. Int J Cancer. 1990;46:796-800. [PubMed] [Google Scholar].

17. Ritte R, Lukanova A, Berrino F, Dossus L, Tjønneland A, Olsen A, Overvad TF, Overvad $\mathrm{K}$, Clavel-Chapelon F, Fournier A, et al. Adiposity, hormone replacement therapy use and breast cancer risk by age and hormone receptor status: a large prospective cohort study. Breast Cancer Res. 2012;14:R76.

18. Giles LC, Glonek GFV, Moore VM, Davies MJ and Mary A Luszcz. RLowerrage at menarche affects survival in older Australian women: results from the Australian Longitudinal Study of Ageing. BMC Public Health 2010, 10:341. [Cited 6 November 2019]. Available from: http://www.biomedcentral.com/14712458/10/341.

19. Zhang Q, Liu LY, Wang F, Mu K, Zhigang Yu. The changes in female physical and childbearing characteristics in china 
and potential association with risk of breast cancer. Zhang et al. BMC Public Health 2012, 12:368. [Cited 6 November 2019]. Available from: http://www.biomedcentral.com/14712458/12/368.

20. Dall GV, Britt KL. Estrogen effects on the mammary gland in early and late life and breast cancer risk. Front Oncol. 2017;7:110. [PMC free article] [PubMed] [Google Scholar].

21. Horn J, Asvold BO, Opdahl S. et al. Reproductive factors and the risk of breast cancer in old age: a Norwegian cohort study. Breast Cancer Res Treat. 2013;139:237-243. [PubMed] [Google Scholar].

22. Wu ZJQ, Yan-qiao ZM, Chunrong C: Relationship between menstrual and reproductive factors and female breast cancer in china: meta-analysis. Modern Preven Med 2010, 37:1262-1264.

23. Rosner B, Colditz GA, Willett WC. Reproductive risk factors in a prospective study of breast cancer: the Nurses' Health Study. Am J Epidemiol. 1994;139:819-835. [PubMed] [Google Scholar].

24. Collaborative Group on Hormonal Factors in BreastCancer. Breastcancer and breastfeeding: collaborative reanalysis of individual data from 47 epidemiological studies in 30 countries, including 50302 women with breast cancer and 96973 women without the disease. Lancet. 2002;360:187-195.

25. Ranasinghe HM, Ranasinghe N, Rodrigo C, Seneviratne RDA, Rajapakse S. Awareness of breast cancer among adolescent girls in Colombo, Sri Lanka: a school based study. BMC Public Health 2013, 13:1209. [Cited 6 November 2019]. Available from: http://www. biomedcentral.com/1471-2458/13/1209.

26. Liu LY, Wang F, Yu LX, Ma ZB, Zhang Q, Gao DZ, et al. Breast cancer awareness among women in Eastern China: a crosssectional study. BMC Public Health 2014, 14:1004, [Cited 8 November 2019]. Available from: http://www.biomedcentral.com/14712458/14/1004.

27. Thu HN, Eriksson B, Khanh TT, Petzold M, Bondjers G, Kim CNT, Thanh LN, Ascher H.Breastfeeding practices in urban and rural Vietnam. [Cited 8 November 2019]. Available from: BMC Public Health 2012, 12:964 http:// www.biomedcentral.com/1471-2458/12/964. 